\title{
多発子宮筋腫のため診断に苦慮した卵管間質部妊娠の一例
}

\author{
原三信病院 婦人科
}

貴島雅子、片岡惠子、松枝さやか、津田知輝

\section{A diagnostically challenging case of interstitial ectopic pregnancy with multiple myomas}

\author{
Masako Kijima, Keiko Kataoka, Sayaka Matsueda, Tomoteru Tsuda \\ Department of Gynecology, Harasanshin Hospital, Fukuoka
}

\begin{abstract}
Interstitial ectopic pregnancy is rare but the frequency is increasing. It is important to diagnose and treat at an early stage to avoid massive hemorrhage due to rupture. We report a diagnostically challenging case of interstitial ectopic pregnancy associated with multiple myomas. A 34-year-old woman (gravida 0) was referred to our hospital because of possible ectopic pregnancy. She was pregnant by artificial insemination on the 36th day of her last menstrual period; however, a gestational sac (GS) was not seen in the uterine cavity and the serum human chorionic gonadotropin (hCG) level was $2,993 \mathrm{mIU} / \mathrm{ml}$. Laparoscopic surgery was performed the same day. Intraoperative examination revealed that the uterus was enlarged by multiple myomas; the bilateral adnexa were normal in appearance. Villi were not observed intraperitoneally. Intrauterine curettage was performed, but only decidual tissue was histopathologically confirmed. Serum hCG increased to 2,555 $\mathrm{mIU} / \mathrm{ml} 10$ days after surgery, but a GS was still not observed. Enhanced computed tomography was performed because the pregnancy status was uncertain. An enhanced cystic mass was observed, suggesting a right interstitial ectopic pregnancy. Repeat laparoscopic surgery was performed. After local injection of vasopressin into the right fundus, the uterine wall was incised and villus-like tissue was confirmed in the interstitial portion of the right tube. We removed villi as much as possible and sutured the myometrium. Villi were confirmed histopathologically. Serum hCG promptly decreased and the postoperative course was uneventful.
\end{abstract}

Key words: interstitial pregnancy, multiple myomas, laparoscopic surgery

\section{緒言}

近年、典型的な異所性妊娠では、続発性無月経 を伴う下腹部痛や不正性器出血などの症状、超音 波断層法の所見、血中hCG值の上昇などにより比 較的早期に診断がつく。着床部位が不明瞭な場合 は頻回な経腟超音波断層法（transvaginal sonography：TVS）や血中hCG值の推移、子宮 内容除去術や診断的腹腔鏡などを行いながら診療 を進めることもある。今回、異所性妊娠を強く疑 い頻回な診察や子宮内容除去術および診断的腹腔 鏡を行うも、多発子宮筋腫のため着床部位の特定 に至らず診断に苦慮した卵管間質部妊娠の症例を
経験したので報告する。

\section{症例}

34歳 未経妊

$156 \mathrm{~cm} \quad 81.5 \mathrm{~kg}$ BMI33.5

既往歴：特記事項なし

月経歴：初経11歳 28-30日型 過多月経なし

月経困難なし

現病歴：24歳の頃より月経不順のため低用量ピル を内服していた。25歳時に結婚し低用量ピルの内 服を中止したが、 1 年半の不妊期間あり当科を受 診し、内診およびTVSで異常を認めなかった。 その後受診なし。32歳時の健診で初めて子宮底部 

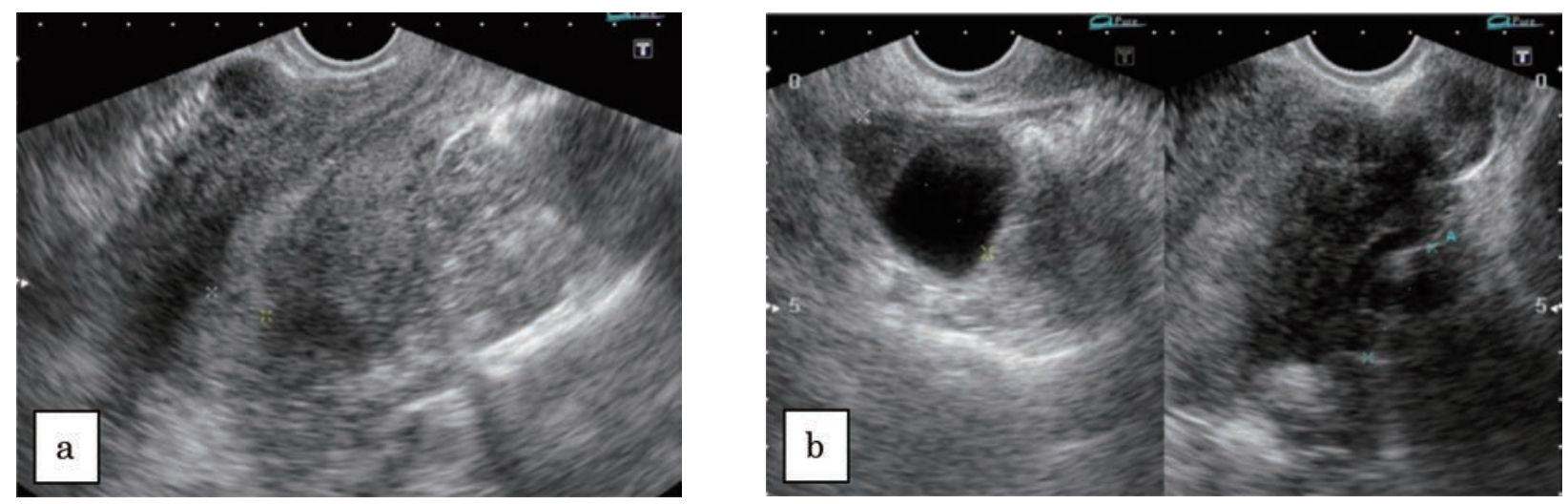

図 1 初診時の経胵超音波断層法

子宮内にGSを認めず（a)、また両側付属器領域に腫瘤を認めなかった (b)。

右側に $4.5 \mathrm{~cm}$ 大の筋層内筋腫を指摘されたが、症 状はなく経過観察となっていた。34歳時に挙児希 望のため前医を受診した。多囊胞性卵巣症候群に よる排卵障害、男性因子による不妊症の診断で、 クロミフェン療法下に人工授精（artificial insemination with husband's semen : AIH）を開 始された。4 回目のAIHを施行し（右卵巣に成熟 卵胞あり)、妊娠 5 週 2 日目に妊娠反応陽性とな ったが、子宮内に胎囊（gestational sac: GS）を 認めなかった（図 1 )。2 日後の再検でもGSを認 めないため、妊娠 5 週 4 日目に異所性妊娠を疑わ れ当科紹介受診。初診時、下腹部痛はないが少量 の褐色帯下を認めた。TVSで子宮内膜は $13 \mathrm{~mm}$ で 子宮内にGSを認めず、両側付属器の腫大はなか った。血中hCG值は2993mIU/mlと高值であった。 AIHによる妊娠であり、妊娠週数は確かであるた め、異所性妊娠を強く疑った。数日の待機は可能 であったかもしれないが、異所性妊娠の破裂は妊 娠 5-9 週の妊娠初期でも起こりうることであ $り^{1,2)}$ 、異所性妊娠の可能性が憂慮されること、妊 娠初期でも破裂のリスクを有することを説明し た。次回妊娠のことを考慮されており、早期では あったが、同日腹腔鏡手術を行った。子宮底部右 側に手拳大、底部左側の卵管付着部位に小鷄卵大、 その間に母指頭大の筋層内筋腫を認め、両側付属 器は正常外観であった（図 2 )。腹腔内を十分に 検索したが、着床部位の特定はできなかったため、 不全流産を疑い子宮内容除去術を行った。術後 3 日目の血中hCG值は $1810.7 \mathrm{mIU} / \mathrm{ml}$ と低下傾向で あり一旦退院したが、病理組織診断は脱落膜組織 のみであった。術後10日目の血中hCG值は $2555.4 \mathrm{mIU} / \mathrm{ml}$ と再び上昇していたが、TVSで子 宮内にGSを認めず着床部位は不明であった。緊 急のMRI検查は難しいため、妊娠 6 週 5 日目に造
影CT検査を施行したところ、右卵管間質部に辺 縁が強く増強される $22 \mathrm{~mm}$ 大の囊胞性構造を認め た（図 3 )。右卵管間質部妊娠を強く疑い、再度 腹腔鏡手術を施行した。臍部に $10 \mathrm{~mm}$ のカメラポ 一ト、下腹部左右と臍高左側に $5 \mathrm{~mm}$ トロッカー を留置し、パラレル法で行った。両側付属器は正 常外観で、腹腔内に出血を認めなかった。術前の 造影CT検査で子宮底部右側の筋腫近傍に増強さ れる領域を指摘されていたため、子宮底部右側の 筋腫周囲にバソプレシンを局注すると青紫色に変 化した。同部位をモノポーラで切開したところ、 右卵管内腔に到達し絨毛様組織を確認した。同部 位の組織を可能な限り摘出し、その周囲をバイポ ーラで焼灼した。 $1-0$ 吸収糸で筋層と漿膜をZ 縫合で 1 層に縫合閉鎖し、癒着防止材を貼付して 手術を終了した（図 4)。術後診断は右卵管間質 部妊娠で、術中出血量は少量であった。病理組織 検査で絨毛組織を認め、術後の血中hCG值は速や かに低下し、再手術後 9 日目には陰性となった。

\section{考察}

卵管間質部妊娠は卵管妊娠の $2-4 \%$ 程度と稀 である ${ }^{3)}$ 。子宮筋層からの豊富な血流により破裂 時には大量出血を引き起こし、死亡率は $2-2.5 \%$ と他部位の異所性妊娠と比して高い ${ }^{3)}$ 。診断は一 般的に続発性無月経、下腹部痛、不正性器出血な どの症状やTVSの所見、血中hCG值の上昇などに より総合的に行う。リスクファクターとしては、 異所性妊娠の既往、卵管切除術の既往、体外受精 を含む高次生殖医療、骨盤腹膜炎の既往、子宮奇 形などが挙げられる ${ }^{3,4)}$ 。卵管間質部妊娠のTVS の所見として、(1)子宮内腔にGSがない、(2)GSが 子宮内腔より $1 \mathrm{~cm}$ 以上離れて認められる、(3) GS を薄い子宮筋層が覆っている、という 3 つの項目 

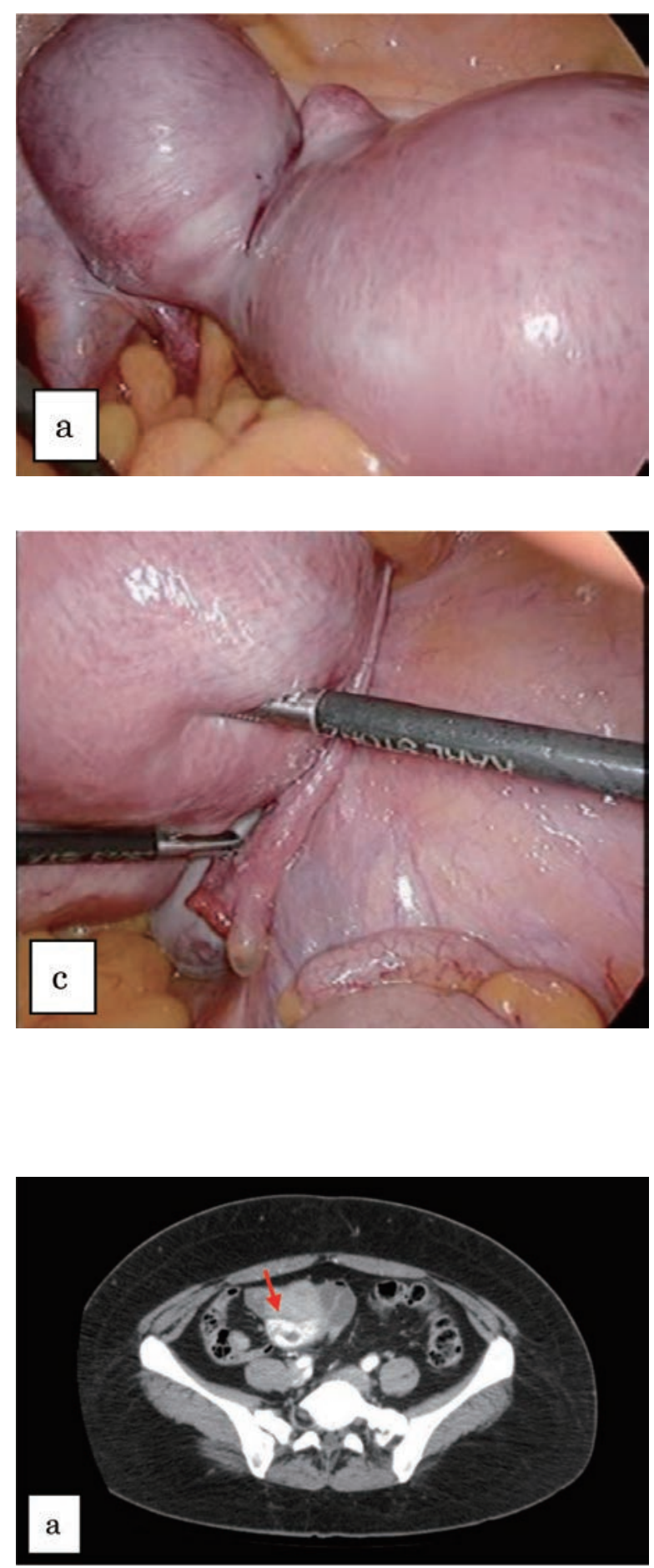

図3 造影 $\mathrm{C}$ 早期相 ( $\mathrm{a}$ : 水平断 $\mathrm{b}$ : 冠状断)

右卵管間質部に辺縁が強く増強される22mm大の囊胞性構造を認めた ( bの矢印（乙）は内膜、（凹）は筋腫を示す。

を満たす場合に間質部妊娠が示唆されるとの報告 がある5,6)。また、interstitial line signともいわれ る、GSと子宮内腔との間のエコーラインの存在 は卵管間質部妊娠において感度、特異度とも高い と報告されている ${ }^{4,7)}$ 。異所性妊娠の診断にはTVS が有用ではあるが、診断がつかない場合や着床部 位が不明である場合にはMRI検査や造影CT検査 を参考にすることもある ${ }^{8,9)}$ 本症例では多発子宮

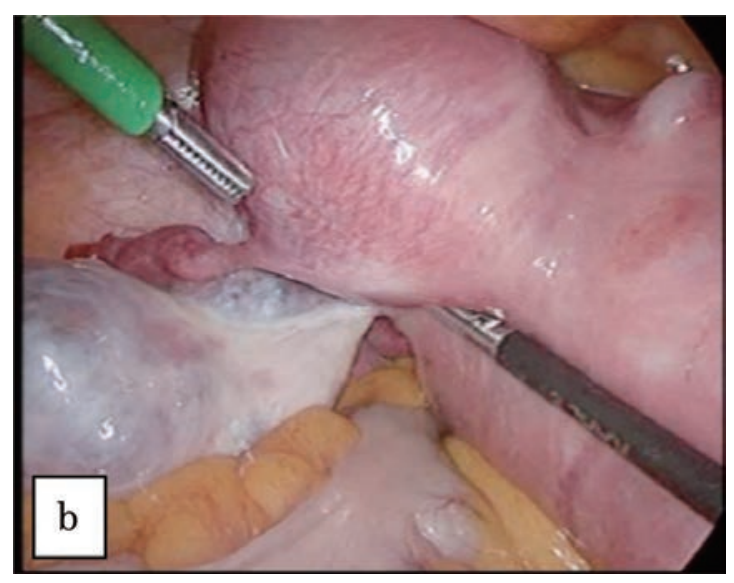

図2 初回手術時。子宮底部右側に手拳大、底部左側の卵管付 着部位に小鶏卵大、その間に母指頭大の子宮筋腫を認め た (a)。両側付属器は正常外観であった $(b, c) 。$

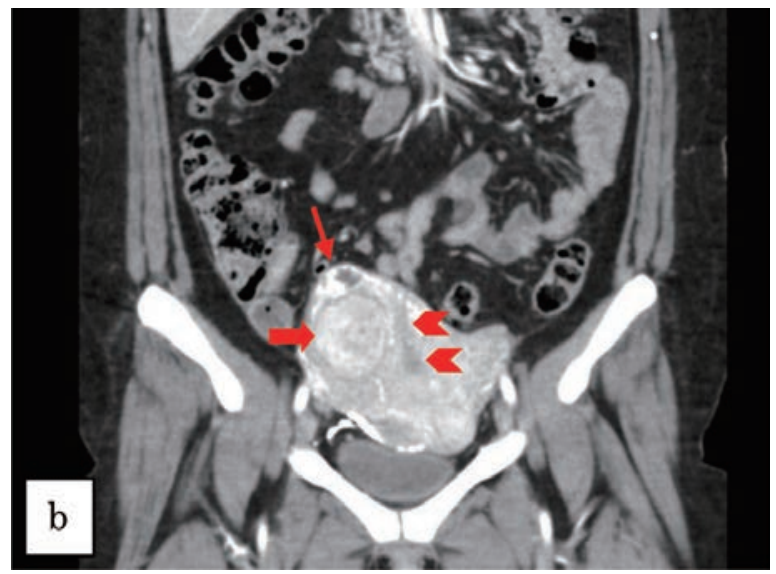



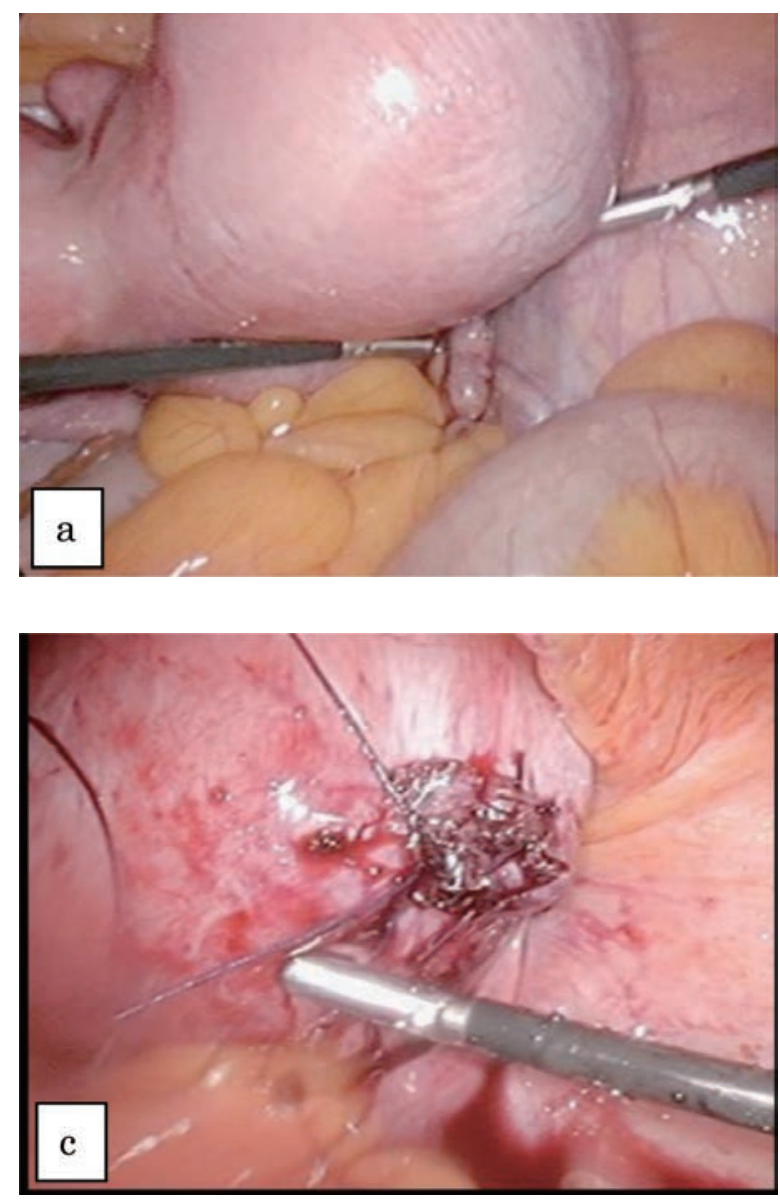

る。MRI検査ではより詳細に着床部位を同定する ことが可能である。造影CT検查では襄胞周囲が 強く造影され、TVSのカラードップラーでみら れるring of fire signに相関するような所見がみ られる ${ }^{9,10-12)}$ 。本症例でも周囲を強く造影される囊 胞構造を確認でき、間質部妊娠に合致する所見と 考えられた。強く造影される付属器腫瘤は、付属 器膿瘍や卵巣腫瘍、黄体囊胞との鑑別を要するが、 増強の程度や囊胞の大きさにより鑑別は比較的容 易である ${ }^{13)}$ 。放射線被曝や造影剂の使用の問題は あるが、CT 検査は早急に利用できる画像診断法 であり、出血点の同定が可能であり、また虫垂炎 など他の急性腹症を呈する疾患との鑑別もできる ため、破裂が疑われる場合や緊急時には有用であ $3^{12)}$ 。Tulandiらは、卵管間質部妊娠32症例中で 破裂した14例はすべて12週未満であったと報告し ている ${ }^{3)}$ が、妊娠 $6-8$ 週での破裂の報告も散見 され $れ^{5,12,14,15)}$ 、卵管間質部妊娠の破裂は 12 週未満の 妊娠初期のいつでも起こり得ることである ${ }^{8)}$ 。診 断の遅れが致命的となるため、診断が困難な場合 にはMRI検査や造影CT検查も選択肢の 1 つとな る $^{16)}$ 。

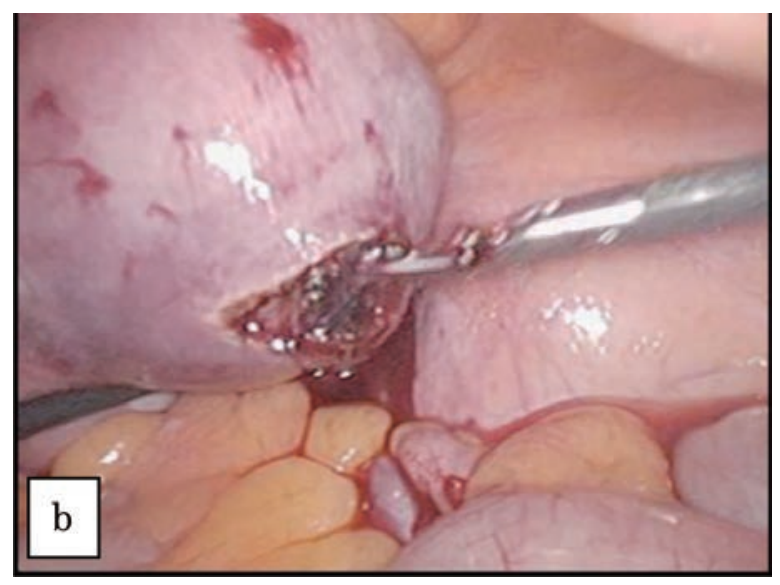

図42 回目手術時。子宮底部右側の子宮筋腫近傍の卵管間質 部に、青紫色にやや腫脹した妊娠部位と思われる所見を 認める (a)。右卵管間質部の絨毛組織を可能な限り摘出 した (b)。子宮卵管角部の切開部を吸収糸で縫合した (c)。

卵管間質部妊娠の治療については、以前は診断 の遅れにより開腹による子宮全摘出や子宮卵管角 楔状切除が行われてきたが、近年は早期発見が可 能となったことや腹腔鏡手術技術の向上により、 腹腔鏡下に子宮卵管角切除や卵管間質部切開が行 われるようになってきた。Tulandiらは、卵管間 質部妊娠 32 症例中、11症例（切除 8 例、切開 3 例） が腹腔鏡下に治療され、子宮卵管角切除の 1 例を 除き追加治療を行わずに治療されたと報告してい る ${ }^{3)}$ 。Lauらのレビューでは、腹腔鏡手術 22 症例 (切 除14例、切開 7 例含む) ですべて成功したと報告 している ${ }^{17)}$ 。本症例では腹腔鏡下子宮卵管角楔状 切除を予定していたが、術中所見で着床部位が子 宮筋腫近傍の卵管間質部であったこと、また術中 に卵管間質部線状切開を行ったところ絨毛組織を 摘出できたことより、着床部位周囲の子宮卵管角 部の切除は行わなかった。バソプレシンの局注を 行ったうえで、腹腔鏡下卵管間質部切開を施行し、 術中出血は少量でトラブルなく終了した。組織学 的に摘出組織内に䄉毛組織を確認し、また術後の 血中hCG值も順調に低下しており、術後経過は良 好であった。 
卵管間質部妊娠治療後の妊娠では、妊娠・分婏 中の子宮破裂の報告もみられるため、注意深く観 察する必要がある ${ }^{18-20)}$ 。保存的治療後に菲薄化し た筋層の部分で破裂したのではないかとの推測も あり、外科的に保存的治療を行う場合は、子宮角 部の筋層を適切に縫合することが重要であるとさ れている ${ }^{17)}$ 。GSの直径 $3.5 \mathrm{~cm}$ 以下では卵管切開、 $4 \mathrm{~cm}$ 以上では切除を行うとの報告もある ${ }^{21)}$ が、 未破裂でGSが小さなものであれば、バソプレシ ンの使用や筋層の適切な縫合により、筋腫合併例 においても腹腔鏡による治療は安全に施行可能で あると考える。Agdiらは卵管間質部妊娠後の分 婏中の子宮破裂の回避のため、帝王切開による分 婏を勧めており ${ }^{18)}$ 、当科でも同様に対応している。 卵管間質部妊娠治療後の妊娠・分娩中の破裂のリ

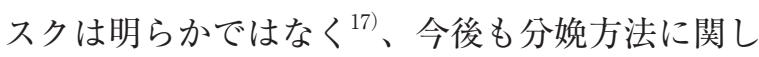
ては更なる検討が必要である。

\section{結語}

生殖医療の発達により、体外受精、高齢出産が 増加しており、今回のように子宮筋腫を合併した 異所性妊娠は今後も増加していくと考えられる。 異所性妊娠においては診断の遅れが生命の危険を 招くこともあるため、着床部位の特定が困難であ る場合には、MRI検查を考慮すべきであり、また 緊急時には造影CT検査も許容されると考える。 また、筋腫を合併した卵管間質部妊娠症例におい ても、バソプレシンの使用や筋層の適切な縫合に より、腹腔鏡下の子宮卵管角切除や卵管切開は選 択肢の 1 つとなる。

本論文の要旨は第11回九州産婦人科内視鏡手術 研究会において発表した。

\section{文献}

1) Malatyalioglu E, et al. : CA-125 levels in ruptured and unruptured tubal ectopic pregnancyes. J Obstet Gynecol Res. 2006 ; 32 (4) : 422-427.

2 ) Saxon D, et al. : A study of ruptured tubal ectopic pregnancy. Obstet Gynecol. 1997 ; 90(1) : 46-49.

3) Tulandi T, et al. : Interstitial pregnancy: Results Generated From the Society of Reproductive Surgeons Registry. Obstet Gynecol. 2004 ; 103 (1) : 47-50.

4) R Rastogi, et al. : Interstitial ectopic pregnancy: A rare and difficult clinicosonographic diagnosis. J Hum Reprod Sci. $2008 ; 1$ (2) : 81-82.

$5 ）$ 河北貴子他：当院で経験した卵管間質部妊娠5症例.
Tokushima Red Cross Hospital Medical Journal. 2012 March ; 17 (1) : 21-25.

6 ) Timor-Tritsch IE, et al. : Sonographic evolution of corneal pregnancies treated without surgery. Obstet Gynecol. $1992 ; 79$ : 1044-1049.

7 ) Ackerman TE, et al. : Interstitial line : Sonographic finding in interstitial (cornual) ectopic pregnancy. Radiology. 1993 ; 189 : 83-87.

8 ) Botros R, et al. : Challenges in the diagnosis and management of interstitial and cornual ectopic pregnancies. Middle East Fertility Society Journal. $2013 ; 18: 235-240$.

9 ) Filhastre $M$, et al. : Interatitial pregnancy : role of MRI. Eur Radiol. $2005 ; 15:$ 93-95.

10) Kao LY, et al. : Beyond Ultrasound : CT and MRI of Ectopic Pregnancy. American Journal of Roentgenology. 2014 ; 202 : 904-911.

11) Pham H, et al. : Adnexal ring of ectopic pregnancy detected by contrast-enhanced CT. Abdom Imaging. 2007 ; 32 (1) : 56-58.

12) Miciej M, et al. : Ruptured ectopic pregnancy diagnosed with computed tomogramphy. Pol J Radiol. 2010 ; 75 (4) : 44-46.

13) Shin BS, et al. : Incidental Detection of Interstitial Pregnancy on CT Imaging. Korean J Radiol. 2010 ; 11 (1) : 123-125.

14) Savvidou MD, et al. : Conservative surgical management of ruptured interstitial pregnancy. Acta Obstet Gynecol Scand. 2006 ; 85 (5) : 629-631.

15）濱地勝弘他：当科で治療した卵管間質部妊娠 12 症例 の検討. 日本産婦人科内視鏡学会雑誌. $2006 ; 22$ (2) : 403-407.

16）戸澤晃子他：卵管間質部妊娠 8 例における腹腔鏡下卵 管角切除術の検討. 日本産婦人科内視鏡学会雑誌. $2016 ; 31(2): 423-428$.

17) Lau S, et al. : Conservative medical and surgical management of interstitial ectopic pregnancy. Fertility and Sterility. $1999 ; 72$ (2) : 207-215.

18) Agdi M, Tulandi T. : Surgical treatment of ectopic pregnancy. Best Pract Res Clin Obset Gynaecol. $2009 ; 23$ (4) : 519-527.

19) Weissman A, et al. : Uterine rupture following conservative surgery for interstitial pregnancy. Eur J Obstet Gynecol Reprod Biol. 1992 ; 44 : 237-239.

20) Downey GP, et al. : Spontaneous uterine rupture during subsequent pregnancy following non-excision of an interstitiall ectopic gestateon. Br J Obstet Gynecol. 1994 ; $101:$ 162-163.

21) Fraj R, et al. : Manegement of cornual(interstitial) pregnancy. The Obstetrician \& Gynaecologist. $2007 ; 9: 249-255$.

投稿日：2016年 12 月 7 日 採択日：2017年 3 月 21 日 